RUNNING HEAD: WHY ARE ANIMATE DISHES SO DISTURBING?

\title{
Why are animate dishes so disturbing?
}

Charles Spence, Crossmodal Research Laboratory

Department of Experimental Psychology, University of Oxford, Oxford, UK

WORD COUNT: 5,900 WORDS

RESUBMITTED TO: INTERNATIONAL JOURNAL OF GASTRONOMY \& FOOD SCIENCE

DATE: 30 $0^{\text {th }}$ June 2018

Correspondence to: Charles Spence, Department of Experimental Psychology,

University of Oxford, Oxford, OX1 3UD, UK.

E-mail: charles.spence@psy.ox.ac.uk 


\begin{abstract}
Most foods are relatively static on the plate. Food that moves, especially if it does so in an animate manner, captures our attention in a way that would seem to play to society's growing interest with 'food porn'. At the same time, however, most diners appear to find such movement on the plate or in the bowl rather disconcerting to say the very least. Such animacy may be aversive, 'horrifying', in fact, being a term that one sometimes sees used in this context. According to one suggestion, this may be because of a primordial fear of asphyxiation on eating food that still has the capacity to move of its own volition. According to others, however, there may also be something of a taboo around harming living things that many meat eaters try to mitigate by, for example, not calling the animals they eat by the name of the beast: Think steak or beef for cow and pork chop or bacon for pig. It may simply be that it is harder to suppress such thoughts related to the life that was lost, what some call the 'meat paradox', when food is animate. The breaking of some sort of taboo might also help to explain the excitement that some feel when they think about eating something that moves. In this article, I provide a brief historical overview of the diner's / chef's / advertiser's fascination with the visual transformation of food on the plate or in food advertising. I take a look at movement, both animate and inanimate, as well as other kinds of transformations, such as foods that change colour before the diner's very eyes. I also look at how technological advances are increasingly starting to offer the creative chef/food designer the opportunity to bring food to life in a way that doesn't necessarily trigger any concerns with animal welfare, nor threaten the diner with asphyxiation.
\end{abstract}

KEYWORDS: ANIMACY; FOOD PORN; MOVEMENT; TRANSFORMATION; DEAD; FRESHNESS; COLOUR-CHANGING FOODS; DIGITAL TECHNOLOGY. 


\section{Introduction}

Everyone likes to eat food that is fresh. What few of us like to do, however, is to eat food that is still alive (see Spence, 2017). The tension here, in terms of the language we use to describe the food we eat, was entertainingly captured in a line from Steve Coogan and Rob Brydon's TV series The Trip where, after a waiter introduces a dish as 'resting', Brydon points out: "Rather optimistic to say they're resting. Their days of resting have been and gone. They are dead.” (quoted in Poole, 2012, pp. 44-45). Of course, while factually correct, 'dead' just feels like a descriptor that should not, and probably never has, appeared on a restaurant menu before. The problem, I suspect, is not that 'dead' is a redundant, and hence unnecessary, term because the diner already assumes that whatever creature went into their meal will have long since breathed its last. Rather, I believe that the problem with this particular descriptor is that it reminds the diner of what happened to their dinner before it reached their table. ' 'Dead' is certainly not a descriptor that is associated with freshness in the mind of the consumer. And whatever the term freshness actually means to the consumer/diner (see Gray, 2018), it is undoubtedly something that many researchers firmly believe that consumers want to associate with the food and drink they consume (e.g., Roque, Auvray, \& Lafraire, 2018; Roque, Lafraire, Spence, \& Auvray, submitted).

Most western diners would, after all, rather not think too much about how their dinner was dispatched. Indeed, widespread cross-cultural evidence now supports the view that humans do not like the idea of killing animals to obtain the meat they eat (Simoons, 1994). This is part of the so-called 'meat paradox' (e.g., Bastian \& Loughnan, 2017; Loughnan, Bastian, \& Haslam, 2014; Loughnan, Haslam, \& Bastian, 2010). The suggestion here is that meat eaters maintain two opposing views, on the one hand not wishing to harm creatures and the other liking meat. According to various authors, meat-eaters may try to reduce this conflict by trying to reduce their concern for the animal suffering, e.g. by giving the meat of the animal another name when we eat it pork chops instead of pig, beef or steak instead of cow (e.g., Hoogland, de Boer, \& Boersema, 2005; see also Plous, 1993).

According to Paul Rozin. meat's "high appeal to the human palate and excellent short-term nutritional value are pitted against concerns about... the immoral treatment of animals"'. At the very least one can say that there is some cognitive dissonance that may be in search of

\footnotetext{
${ }^{1}$ One might also wonder about the sense in calling one's new drink brand 'Liquid Death' as happened recently (see Nudd, 2018).
} 
resolution. It may therefore be that we meat eaters find it harder to suppress our concern for the animal suffering when we are reminded of the life of the animal we are eating by movement on the plate. Edward O. Wilson's (1984, p. 1) notion of biophilia, which the biologist defines as - "the innate tendency to focus on life and lifelike processes" may also be relevant here. And both the meat paradox and the idea of an innate biophilia response may, in fact, be linked with the increasing move toward vegetarianism that has been seen in recent years (Stickings, 2018).

\section{$\underline{\text { Attention-capturing food }}$}

Visual movement, no matter whether it is food-related or not, captures our attention (e.g., Franconeri \& Simons, 2003). ${ }^{2}$ According to research by Pratt, Radulescu, Guo, and Abrams (2010), animate motion is even more attention-capturing than the inanimate variety. ${ }^{3}$ From an evolutionary perspective, this is thought to stem from the need to successfully detect both predators and prey (see also New, Cosmides, \& Tooby, 2007). As Pratt et al. (2010, p. 1724) put it: “For most of humans' evolutionary history, detecting potential prey and predators in the environment was crucial for survival. Ancestors that failed to find the protein-rich food sources supplied by animals, or became that food source for other animals, would cease to be part of the family tree.” Meanwhile, according to other research, we also express a tendency to want to grasp those objects that move too (e.g., Cian, Krishna, \& Elder, 2014; Vingerhoets, 2014).

At the same time, however, a growing body of empirical research also now shows that our brains rapidly categorize images of food in terms of their energy density (e.g., Toepel, Knebel, Hudry, Lecoutre, \& Murray, 2009). Our attentional resources are almost immediately preferentially allocated to the energy-dense objects (i.e., foodstuffs) in the scene, or on the plate/package, and/or in the food advert (see Harrar, Toepel, Murray, \& Spence, 2011; Sawada,

\footnotetext{
${ }^{2}$ It has been argued that much of the success of recent advertising campaigns for supermarket food can be put down to the fact that the food is nearly always in motion (e.g., Spence, 2017). In fact, an informal analysis of the food commercials shown in the highly valued advertising slots during the US Super Bowl revealed that two-thirds showed food in motion in the years 2012-2014 (see Gvili, Tal, Amar, Hallak, Wansink, Giblin, \& Bommelaer, 2015).

${ }^{3}$ It is an interesting question as to what the minimum conditions are for the ascription of animacy to a stimulus (cf. Auvray, Philipona, O’Regan, \& Spence, 2007; Scholl, \& Tremoulet, 2000; Tremoulet \& Feldman, 2000, 2006, on this theme).
} 
Sato, Toichi, \& Fushiki, 2017). It is this that helps to explain why it is that energy-dense food sources in motion (be it real or implied) are so attention-capturing. Hence, the almost irresistible allure of oozing egg yolks and melting cheese; These 'protein in motion' advertising shots, what some have evocatively labelled 'Yolk Porn' (see Carlo, 2015), are all the rage in food advertising these days (see Spence, 2017). ${ }^{4}$ As is becoming ever clearer, capturing the attention of one's viewer is very much the name of the game in the age of Instagram feeds, such as 'The art of plating' (http://theartofplating.com/; see Spence, Okajima, Cheok, Petit, \& Michel, 2016, for a review), not to mention when trying to capture the attention of the easilydistractible Millennial consumer.

That said, our aversion to externally-generated, especially animate, movement on the plate or in the bowl (i.e., to something that appears still to have a life of its own) presumably also relates to some more primordial fear of asphyxiation (cf. Allen, 2012; Bowman, 2016; Hubbard, 2013), were that moving thing to be transferred from plate to mouth. Indeed, anyone who has been confronted with the live squid tentacles that are sometimes served in Korean restaurants will likely know exactly what I am talking about. As such, the irony is that that while our visual attention is undoubtedly drawn to food in motion, once that food enters the oral cavity, movement is the last thing we want. This deep-seated aversion to things wiggling around in our mouths, and worse still, in our throats, was presumably partly what caused such a stir when Noma served live ants a few years back. The entomophagy angle not helping much here either (Deroy, Reade, \& Spence, 2015). ${ }^{5}$ I am also reminded of by brief stay in a North American boarding school 30 years ago when one of the school prefects would have to swallow a live goldfish every time the home team won (see Spence, 2017). ${ }^{6}$

\footnotetext{
${ }^{4}$ One video of a melting chocolate dessert that swept the internet a couple of years ago was actually described as 'hypnotic' by a number of commentators (Hodgkin, 2016; Ridley, 2014). Think also of that most comforting of dishes the cheese fondue, gently bubbling away on the flame (see Spence, 2018). Volcanic chocolate puddings, and possibly also dramatically deflating soufflés also have dynamic properties that may well capture the attention too.

${ }^{5}$ In fact, one might wonder to what extent it is the surprising awareness movement of the bug in our food that gives rise to some of the disgust we associate with entomophagy? "The concept of what is not acceptable as food in English culture is well conveyed by the schoolboy's question "What is worse that finding a maggot in your apple?" - "Finding half a maggot.”" (Holt, 1885/1992, Why not eat insects?, p. 6). The situation (i.e., shifting people towards more insect matter in their diet) not being helped by portrayals of live-insect eating in TV shows like 'I'm a Celebrity Get Me Out of Here' (see Dunphy, 2017). That said, there is one Sicilian sheep's cheese, Casu Marzu, that crawls with live maggots, the latter's excretions adding a certain 'Je ne sais quoi' to the flavour, apparently (Persad, 2015).

${ }^{6}$ According to my colleagues, this practice certainly isn't restricted solely to Canadian boarding schools, where your author first came across the habit. According to Wikipedia
} 
Disgust would seem to be a relevant notion here. The relevant question here then becomes one of what it is that provokes disgust? According to some authors it is matter out of place (Douglas, 1972). Indeed, it is interesting to note here that according to Sahlins (1976) disgust responses may be elicited by category confusion. Categorization of food, e.g., into the raw and the cooked, is one of the key themes in Douglas's classic (1972) article, and animate food may indeed cross that boundary. Obviously, there may also be a link to Lévi-Strauss’s (1970) early work on The Raw and the Cooked and the use of food as a differentiator of people's/cultural groups. Probing the various causes of disgust reactions in the world of food might, in the years ahead, prove fruitful when trying to come to an understanding of what it is about eating animate foods that we so dislike. That said, when contemplating disgust, it should, of course, be borne in mind that such reactions typically have cultural roots (see Miller, 1991). Certainly, the research suggests that there may be some relevant cross-cultural differences in attitudes to be aware of here e.g., between the French and Chinese in terms of their attitude toward, and way of dealing with, the meat paradox (see Tian, Hilton, \& Becker, 2016).

\section{Dancing delicacies from the Far East}

Creative chefs in the Far East have give the illusion of animacy in a number of ways, including by sprinkling dried bonito flakes (hanakatsuo) on a hot dish as it is served. The steam from the food makes the flakes move as if they were actually dancing. In fact, because of this 'a life of its own' quality, katsuobushi topping is also known as 'dancing fish flakes' (see also Boozedude, 2013a). For me, though, this kind of motion falls somewhere in the 'uncanny valley’ range (i.e., very close to animate motion but just ever so slightly different; cf. Piwek, McKay, \& Pollick, 2014; Strait, Floerke, Ju, Maddox, Remedios, Jung, \& Urry, 2017). ${ }^{7}$

Rather more disturbing, at least according to many of the western press reports on the phenomenon (e.g., Boozedude, 2013b) is what was described in the title of one post as 'Zombie Food: Dancing Squid for Dinner'. ${ }^{8}$ In this case, while the squid (or cuttlefish) itself is already

(https://en.wikipedia.org/wiki/Goldfish_swallowing), the craze was started by a Harvard student but soon spread to many North American colleges/universities.

${ }^{7}$ According to Piwek et al. (2014, p. 271): "The uncanny valley hypothesis states that the acceptability of an artificial character will not increase linearly in relation to its likeness to human form. Instead, after an initial rise in acceptability there will be a pronounced decrease when the character is similar, but not identical to human form (Mori, 1970/2012)."

\footnotetext{
${ }^{8}$ Katsuobushi is the name given to dried, fermented, and smoked skipjack tuna. It is, also known as Bonito flakes when young bonito is used as a cheaper substitute for skipjack tuna.
} 
dead, the addition of soy sauce to the deceased cephalopod results in automatic muscle contraction (triggered by the salt in the soy sauce) thus making the dead squid appear to 'dance' on the plate (Gates, 2013). This dish, known as ‘Odori-don', apparently rose to fame after being served in Japanese sushi restaurant Ikkatei Tabiji, in Hakodate. The dish has become so popular, in fact, that the restaurant has now patented the name.

There is, though, a certain xenophobia to writings on this theme. In the western popular press, for instance, the eating of live seafood is often portrayed as a barbaric tendency engaged in by those is certain parts of East Asia (Dunphy, 2017). In passing, it is worth considering why it should be that all of the dynamic dishes that are served in the Far East revolve around creatures from the sea. Perhaps there is something here to do with the need to make sure that certain meats, like pork, are cooked to avoid parasitic infestation. ${ }^{9}$ Of course, prior to widespread refrigeration this is more likely to have been a common concern. Is the fish focus simply a result of technical/physiological constraints (namely that it is simply easier to keep a fish alive at the dining table while eating, or about to eat, it), or is there a more fundamental difference in the way in which we relate to edible creatures from the land and sea. Food that moves on the plate can be both hypnotic and disturbing. [Squirming of the live abalone and hagfish that one sometimes sees at Korean BBQs. Live drunken shrimp, qiang xia, is soaked in alcohol and eaten while still moving (Cost, 2013). Live shellfish/seafood eaten in Taiwan, Korea, China, and And the Korean dish sannakji consists of pieces cut from a life hangul, or small octopus, and served immediately, often still squirming. It also may be served whole. The octopus may have its revenge, though. (Hubbard, 2013).

Of course, for all those westerners feeling so smug with themselves that they would never do anything so gross as eat something that was still alive, it is worth noting that oysters are also served alive. That said, I suppose oysters don't move much when we eat them fresh with a squirt of lemon on the half shell. In this case, the justification is not a macabre pleasure in eating something that is still alive, but the health and safety angle that as soon, as an oyster dies is starts to become unsafe to eat (see Thomson, 2017).

In passing here, it is perhaps worth noting that in medieval banquets in Europe, the dinner would sometimes appear to come back to life. For instance, the idea behind one dish, called 'How to roast a chicken and bring it back to life again' (Blumenthal, 2013) was to mix a live, but sleeping, plucked and basted chicken with a couple of roasted birds. When the carving

\footnotetext{
${ }^{9}$ Though see https://www.theguardian.com/lifeandstyle/2011/may/26/cooking-pork-safely-the-science.
} 
began at the table, said chicken would wake up, make some startled noises and then run for its life (Lathigra 2013).

\section{Implied movement}

While food in motion works in restaurant, and in video advertisement, it can be much harder to capture in a still picture. All is not lost, however, as the marketing researchers have demonstrated that implied motion not only captures our visual attention (Acik, Bartel, \& Konig, 2014) but can also provide an effective means of conveying notions of freshness too (Gvili et al., 2015). Wansink and his colleagues at Cornell University conducted research showing that we rate a picture of a glass of orange juice as looking significantly more appealing when juice can be seen being poured into the glass than when the image is of a glass that has already been filled. ${ }^{10}$ Both are static images but one implies motion. That was enough to increase the product's appeal. ${ }^{11}$ Indeed, aware of the power of the dynamic image of food, the Kikkoman company $^{12}$ are currently working with researchers over in Holland on dynamic .jpg format for conveying dynamic aspect to the key part of an image with a small bandwidth.

\section{Other kinds of transformation in foodstuffs}

Movement, either real or implied, is of course only one kind of transition that a food might go through. Foods that change their colour have also been seemed desirable at least since ancient times. While in Ancient Rome, until the end of the second century AD, it was the Goatfish (Mullus barbatus and Mullus surmuletus), that would change colour as it died on the table that was highly prized (Andrews, 1949). The fish would be paraded in front of the guests as it died, displaying a rainbow array of colours. Nowadays, though, it is things like the Yumchaa tea (see Blake, 2017) which has the combined benefits both of changing colour (from turquoise it changes into a more appealing deep purple) when the consumer adds lemon (due to the change

\footnotetext{
${ }^{10}$ Note that there has been widespread concern raised about many of Wansink's published results though as yet, this study has not, as far as I am aware, been retracted (https://retractionwatch.com/2017/12/28/another-retraction-appear-cornell-foodscientist-brian-wansink/; https://retractionwatch.com/2018/02/27/after-considerable-intellectual-agony-journal-retractswansink-paper/).

${ }^{11}$ For those of you at home, who may not be able to guarantee that your food moves, another strategy is simply to leave the leaves and/or stems on fruit and vegetables, to help cue freshness.

12 cf. https://www.kikkoman.com/en/news/2017news/01.html.
} 
in $\mathrm{pH}$ ) but also having one of those colours a very much on-trend natural blue (from dried pea flowers; see Spence, submitted). The tea has apparently sold out, highlighting the interest of the consumer in such unusual (dynamically-changing) foods and beverages.

\section{Technological solutions to making your food move}

Nowadays, with concern growing about animal welfare, the very idea of cooking (let alone serving) a creature that is still alive is increasingly unacceptable. Note, here, how some countries (including New Zealand, Italy, and latterly, Switzerland) have recently banned chefs from cooking lobsters alive - they need to be stunned first (Calfas, 2018). Instead, there is growing interest in the use of a range the latest in chemistry and digital technology solutions in order to help make food and drink dynamic/interactive (e.g., Kan, Vargo, Machover, Ishii, Pan, Chen, \& Kakehi, 2016). Everything from levitating plates (see the many offerings from company Levitating X; http://levitatingx.com/) through to the use of ultrasound waves to make the food dance (or vibrate) on the plate (or in the bowl). For instance, Marianna Obrist and her colleagues in Brighton have also been working on a solution (TastyFloats) to levitate drops of food and drink (Ackerman, 2017; Vi, Marzo, Ablart, Memoli, Subramanian, Drinkwater, \& Obrist, 2017). Similarly, others are using sound waves to bring food to life, or at least to make it move or vibrate in front of the diner (e.g., Pangburn, 2015). ${ }^{13}$ Such futuristic combinations of tech and food/drink have certainly captured the attention of the popular press though whether the consumer/diner sees them as anything more than a gimmick remains to be seen!

Rosa Pasta from Loris Tupin, a French industrial designer, is a 'bio-dynamic' 3D model that magically transforms into a rose when placed in boiling water. (Halterman, 2014; Wang, Yao, Zhang, Cheng, Levine, \& Ishii, 2017). Note though that this solution is of more interest in terms of reducing food transportation costs, allowing for the initial flat-packing of the pasta, than necessarily to entertain the diner (Cuthbertson, 2017). What is more, the transformation occurs in the kitchen not at the dining table.

A range of digital technologies are also enabling creatives to bring visual motion to the dinner table/dining environment (Stewart, 2017). ${ }^{14}$ There are technical ways of moving the food by

\footnotetext{
${ }^{13}$ According to Pangburn (2015): "Within the culinary arts, there is now an extreme subculture of food that moves based on sound. No, we're not talking about something like that famous dinner scene in Beetlejuice. This moveable feast, which is called "Speaker Soup," is technological."

${ }^{14}$ https://business.panasonic.co.uk/visual-system/le-petit-chef-brings-visual-mapping-to-the-restaurant-table.
} 
moving the plate or receptacle on which it is placed (Comber, Barden, Bryan-Kinns, \& Olivier, 2015; Comber, Choi, Hoonhout, \& O’Hara, 2014), thus creating new kinds of digital interactions with food.

As mentioned already, however, there is something unpleasant/disturbing about those kinds of movement/transformation that are almost life like, and which perhaps fall into the so-called 'uncanny valley’ (e.g., Piwek et al., 2014;). Minsu Kim's Living Food project falls very much in this space. The project builds on developments in synthetic biology to propose meals that behave like living creatures (Vanhamert, 2013). Thus far, these are more conceptual pieces than dishes that one might actually find on a restaurant menu though. Watching a video of one of these dishes online ${ }^{15}$ really emphasizes the disturbing nature of the movement at the category boundary, where one isn't really sure what one is looking at Strait et al., 2017; Swerdloff, 2013). ${ }^{16}$

\section{Conclusions}

Before concluding, it is worth remembering that most natural food and drink products are in a more or less permanent state of transition - wines age, kimchi ferments, fruits ripen, bread goes stale, hot foods cool and iced drinks warm up, etc., etc. Such slow, or gradual, transitions occur too slowly to capture the consumer's/diner's attention. However, when changes happen at a rate/in a way that appears animate, contradictory effects seem to be elicited in the diner/drinker. On the one hand, we like our food fresh, and there is little that signals freshness like life/movement itself. On the other hand, though, foods that have a pattern of movement that triggers a judgment of animacy also perhaps triggers some deep-seated concern about the danger of asphyxiation (Hubbard, 2013), so priming the notion that this is a food to be avoided. Eating food that moves in an animate manner may also trigger notions of agency, and raises questions about the lives of the animals that may have been lost (and the pain that they might have felt) in making our meal possible (cf. Dawkins, 1980; Magee \& Elwood, 2013). ${ }^{17}$ As

\footnotetext{
${ }^{15}$ E.g., see ‘Living Food by Minsu Kim’; https://vimeo.com/69242107.

${ }^{16}$ Is 'Food in Motion', or 'Meals on Wheels' a good idea for naming a food delivery service? One has to wonder. Perhaps it is best to make sure that the source of that motion is spelled out very clearly, as in the case of 'Meals on Wheels'.

${ }^{17}$ Based on the same premise, before presenting diners with the Picasso dish, chef Jozef Youssef plays an entertaining (and, for some, shocking) soundscapes of a duck being noisily chased around the yard before hearing a final chop (and then silence), to remind the diner of the animal that has been killed in order to prepare the dish
} 
such, it may be the non-motion related transitions/changes happening at a rate that the diner/drinker can perceive that will both capture their attention, as well as priming notions of freshness without triggering concerns about a potential choking hazard, nor reminding the diner of the fate that befell the creatures that go into making up their food. The danger, though, is that it also primes notions of the unnatural/Frankenstein foods.

\section{REFERENCES}

Acik, S. A., Bartel A., \& Konig, P. (2014). Real and implied motion at the center of gaze. Journal of Vision, 14:2.

Ackerman, E. (2017). TastyFloats: A levitating food delivery system. IEEE Spectrum, October $\mathbf{6}^{\text {th }}$. https://spectrum.ieee.org/tech-talk/computing/hardware/tastyfloats-a-levitating-fooddelivery-system.

Allen, J. S. (2012). The omnivorous mind: Our evolving relationship with food. London, UK: Harvard University Press.

Andrews, A. C. (1949). The Roman craze for Surmullets. The Classical Weekly, 42(12), 186188.

Auvray, M., Philipona, D., O’Regan, J. K., \& Spence, C. (2007). The perception of space and form recognition in a simulated environment: The case of minimalist sensory-substitution devices. Perception, 36, 1736-1751.

Bastian, B., \& Loughnan, S. (2017). Resolving the meat-paradox: A motivational account of morally troublesome behavior and its maintenance. Personality and Social Psychology Review, 21, 278-299.

Blake, I. (2017). Too pretty to drink? Sell-out colour-changing tea turns from blue to purple before your eyes (and it's flying off shelves faster than classic Earl Grey). Daily Mail Online, September $2^{\text {th }}$. http://www.dailymail.co.uk/femail/food/article-4910522/The-viral-colourchanging-tea-s-selling-fast.html.

Blumenthal, H. (2013). Historic Heston Blumenthal. London, UK: Bloomsbury.

Boozedude (2013a). Barrafina and Koya Exchange - Freaky “moving” tortilla! Word Press, June 19 $^{\text {th }}$. https://wilkes888.wordpress.com/2013/06/19/barrafina-and-koya-exchange-freakymoving-tortilla/.

Boozedude (2013b). Japanese Dancing Squid... and other 'moving meals'. Word Press, July 24 $^{\text {th }}$. https://wilkes888.wordpress.com/2013/07/24/feature-japanese-dancing-squid-and-othermoving-meals/.

Bowman, L. (2016). Should eating live octopus be made illegal? Metro, November $21^{\text {st }}$. http://metro.co.uk/2016/11/21/should-eating-live-octopus-be-made-illegal-6272296/.

(see Spence \& Youssef, 2016). The idea in this case is that if being reminded of the fate of the animal makes the diner uncomfortable, perhaps they shouldn't be eating meat in the first place! 
Calfas, J. (2018). This country is making it illegal to boil live lobsters. Time, January $\mathbf{1 6}^{\text {th }}$. http://time.com/5103892/switzerland-boil-lobsters/.

Carlo, E. (2015). 22 reasons you should definitely eat the yolk. BuzzFeed, May 30 ${ }^{\text {th }}$. (https://www.buzzfeed.com/emilycarlo/perfectly-captured-moments-of-yolkporn?utm_term=.lpr0Qmmq2\&sub=3791242_5839082\#.uhv02yyrk).

Cian, L., Krishna, A., \& Elder, R. S. (2014). This logo moves me: Dynamic imagery from static images. Journal of Marketing Research, 51, 184-197.

Comber, R., Barden, P., Bryan-Kinns, N., \& Olivier, P. (2015). Not sharing sushi: Exploring social presence and connectedness at the telematic dinner party. In J. H.-J. Choi, M. Foth, \& G. Hearn (Eds.), Eat, cook, grow: Mixing human-computer interactions with human-food interactions (pp. 65-79). Cambridge, MA: MIT Press.

Comber, R., Choi, J. H.-J., Hoonhout, J., \& O’Hara, K. (2014). Designing for human-food interaction: An introduction to the special issue on 'food and interaction design.' International Journal of Human-Computer Studies, 72, 181-184.

Cost, B. (2013). Off the beaten palate: Live drunken shrimp. Shanghaiist, March $\mathbf{2 3}^{\text {rd }}$. http://shanghaiist.com/2013/03/23/off_the_beaten_palate_live_drunken.php.

Cuthbertson, (2017). 'Shape-shifting' pasta could transform food shipping. Newsweek, May $2^{\text {th }}$. http://www.newsweek.com/shape-shifting-pasta-could-transform-food-shipping-615578.

Dawkins, M. S. (1980). Animal suffering: The science of animal welfare. London, UK: Chapman and Hall.

Deroy, O., Reade, B., \& Spence, C. (2015). The insectivore's dilemma. Food Quality \& Preference, 44, 44-55.

Douglas, M. (1972). Deciphering a meal. Daedalus, 101 (1, Myth, Symbol, and Culture; Winter), 61-81.

Dunphy, L. (2017). NOT fine dining! Disturbing footage of restaurant diners eating LIVE seafood - including squirming fish on ice being cut open - reveals grim trend in China. Daily Mail Online, November 20 ${ }^{\text {th }}$. http://www.dailymail.co.uk/news/article-5099831/Diners-eatLIVE-seafood-grim-trend-China.html.

Franconeri, L., \& Simons, D. J. (2003). Moving and looming stimuli capture attention. Perception \& Psychophysics, 65, 999-1010.

Gates, S. (2013). 'Dancing squid' phenomenon: How soy sauce brings a dead creature back to 'life'. Huffington Post, December $2^{\text {nd }}$. https://www.huffingtonpost.co.uk/entry/dancing-squiddead-cuttlefish-soy-sauce_n_2663377.

Gray, L. (2018). Dinner tonight: Two-year-old fish and some six-month-old grapes. The Times, (Times 2), April 10 ${ }^{\text {th }}, 4-5$.

Gvili, Y., Tal, A., Amar, M., Hallak, Y., Wansink, B., Giblin, M., \& Bommelaer, C. (2015). Fresh from the tree: Implied motion improves food evaluation. Food Quality and Preference, 46, 160-165.

Halterman, T. E. (2014). Barilla announces their 3D printed pasta contest winners. 3DPrint.Com, December 22nd. https://3dprint.com/32604/3d-printed-pasta-contest/.

Harrar, V., Toepel, U., Murray, M., \& Spence, C. (2011). Food's visually-perceived fat content affects discrimination speed in an orthogonal spatial task. Experimental Brain Research, 214, 351-356. 
Hodgkin, E. (2016). How to make the chocolate ball dessert taking the web by storm: As hypnotic videos for melting domes go viral, we recreate the treat - with spectacular (and messy) results. Daily Mail Online, February $\mathbf{1 8}^{\text {th }}$. http://www.dailymail.co.uk/femail/food/article3451549/How-make-melting-chocolate-dome-dessert-gripping-web.html.

Holt, V. M. (1885/1992). Why not eat insects? Whitstable, UK: Pryor Publications.

Hoogland, C., de Boer, J., \& Boersema, J. (2005). Transparency of the meat chain in the light of food culture and history. Appetite, 45, 15-23.

Hubbard, A. (2013). Video: 'Dancing' squid seems alive on plate; here's why. LA Times, May 30 $^{\text {th }}$. http://articles.latimes.com/2013/may/30/news/la-dd-dancing-squid-moves-on-plate20130530.

Kan, V., Vargo, E., Machover, N., Ishii, H., Pan, S., Chen, W., \& Kakehi, Y. (2016). Organic primitives: Synthesis \& design of $\mathrm{pH}$-reactive material interfaces: Materials with organic molecules for biocompatible I/O. CHI 2017, May 06 - 11, 2017, Denver, CO, USA.

Lathigra, K. (2013). History man. The Financial Times, October 5/6 (magazine), 11-21.

Lévi-Strauss, C. (1970). The raw and the cooked: Introduction to a science of mythology, I. London, UK: Jonathan Cape. [The whole series in French is Mythologiques: I. Le Cru et le cuit, II. Du Miel aux cendres, III. L'Origine des manières de table (Paris: Pion, 1964-1968).]

Loughnan, S., Bastian, B., \& Haslam, N. (2014). The psychology of eating animals. Current Directions in Psychological Science, 23, 104-108.

Loughnan, S., Haslam, N., \& Bastian, B. (2010). The role of meat consumption in the denial of moral status and mind to meat animals. Appetite, 55, 156-159.

Magee, B., \& Elwood, R. W. (2013). Shock avoidance by discrimination learning in the shore crab (Carcinus maenas) is consistent with a key criterion for pain. Journal of Experimental Biology, 216, 353-358.

Miller, W. I. (1991). Darwin's Disgust. In D. Howes (Ed.), Empire of the senses (pp. 335-356). Oxford, UK: Berg.

Mori, M. (2012). The uncanny valley. In K. F. MacDorman, \& N. Kageki (Trans.), IEEE Robotics and Automation, 19(2), 98-100 (Original work published in 1970).

New, J., Cosmides, L., \& Tooby, J. (2007). Category-specific attention to animals reflects ancestral priorities, not expertise. Proceedings of the National Academy of Sciences, USA, 104, 16598-16603.

Nudd, T. (2018). Can a water called Liquid Death beat the energy drinks at their own game? AdWeek, January 19 ${ }^{\text {th }}$. http://www.adweek.com/creativity/can-a-water-called-liquid-deathbeat-the-energy-drinks-at-their-own-game/.

Pangburn, D. J. (2015). This soup is alive with the sound of music. The Creators Project, September $\mathbf{3 0}^{\text {th }}$. https://creators.vice.com/en_us/article/wnppaw/this-soup-is-alive-with-thesound-of-music.

Persad, M. (2015). Casu Marzu cheese is crawling with live maggots. On purpose. Huffington Post, December $\quad 7^{\text {th }}$. https://www.huffingtonpost.co.uk/entry/casu-marzucheese_us_5661b5e8e4b072e9d1c5c7ae.

Piwek, L., McKay, L. S., \& Pollick, F. E. (2014). Empirical evaluation of the uncanny valley hypothesis fails to confirm the predicted effect of motion. Cognition, 130, 271-277. 
Plous, S. (1993). Psychological mechanisms in the human use of animals. Journal of Social Issues, 49, 11-52.

Poole, S. (2012). You aren't what you eat: Fed up with gastroculture. London, UK: Union Books.

Pratt, J., Radulescu, P. V., Guo, R. M., \& Abrams, R. A. (2010). It's alive! Animate motion captures visual attention. Psychological Science, 21, 1724-1730.

Ridley, L. (2014). Marks and Spencer is bringing back its food porn adverts. Huffington Post, September $\quad 2^{\text {nd }}$. https://www.huffingtonpost.co.uk/2014/09/02/marks-andspencer-foodpudding-advert-this- is- not-just-any_n_5751628.html.

Roque, J., Auvray, M., \& Lafraire, J. (2018). Understanding freshness perception from the cognitive mechanisms of flavor: The case of beverages. Frontiers in Psychology, 8:2360.

Roque, J., Lafraire, J., Spence, C., \& Auvray, M. (submitted). The influence of audiovisual perceptual features on the categorization of freshness in beverages. Manuscript submitted for publication.

Rozin, P. (1996). Towards a psychology of food and eating: from motivation to module to model to marker, morality, meaning, and metaphor. Current Directions in Psychological Science, 5, 18-24.

Sahlins, M. (1976). Culture and practical reason. Chicago, IL: University of Chicago Press.

Sawada, R., Sato, W., Toichi, M., \& Fushiki, T. (2017). Fat content modulates rapid detection of food: A visual search study using fast food and Japanese diet. Frontiers in Psychology, 8:1033.

Scholl, B. J., \& Tremoulet, P. D. (2000). Perceptual causality and animacy. Trends in Cognitive Sciences, 4, 299-309.

Simoons, F. J. (1994). Eat not this flesh: Food avoidances from prehistory to the present. Madison, WI: University of Wisconsin Press.

Spence, C. (2017). Gastrophysics: The new science of eating. London, UK: Viking Penguin.

Spence, C. (2018). Fondue makes a comeback. International Journal of Gastronomy \& Food Science, 12, 14-15.

Spence, C. (submitted). What is so unappealing about blue food and drink? International Journal of Gastronomy \& Food Science.

Spence, C., Okajima, K., Cheok, A. D., Petit, O., \& Michel, C. (2016). Eating with our eyes: From visual hunger to digital satiation. Brain \& Cognition, 110, 53-63.

Spence, C., \& Youssef, J. (2016). Constructing flavour perception: From destruction to creation and back again. Flavour, 5:3.

Stewart, A. (2017). Digital installation transforms restaurant into immersive dining experience. April 19 ${ }^{\text {th }}$. http://mymodernmet.com/teamlab-sagaya-interactive-restaurants/.

Stickings, T. (2018). Eight million Brits 'no longer eat meat' and one in four are set to cut their meat intake within the next year as young people 'opt for vegetarian diets'. Daily Mail Online, April 14 ${ }^{\text {th }}$. http://www.dailymail.co.uk/news/article-5615119/Eight-million-Brits-no-longereat-meat-one-four-set-cut-meat-intake.html. 
Strait, M. K., Floerke, V. A., Ju, W., Maddox, K., Remedios, J. D., Jung, M. F., \& Urry, H. L. (2017). Understanding the uncanny: Both atypical features and category ambiguity provoke aversion toward humanlike robots. Frontiers in Psychology, 8:1366.

Swerdloff, A. (2013). Eating the uncanny valley: Inside the virtual reality world of food. Munchies, April 13 $^{\text {th }}$. https://munchies.vice.com/en_us/article/ezq9zj/eating-the-uncannyvalley-inside-the-virtual-reality-world-of-food.

Thomson, J. R. (2017). Raw oysters are alive until you eat them, in case you didn't know. The question is: When exactly do they die? Huffington Post, May $\mathbf{2 5}^{\text {th }}$. https://www.huffingtonpost.co.uk/entry/raw-oysters-stillalive_us_592582f3e4b0ec129d31130b.

Tian, Q., Hilton, D., \& Becker, M. (2016). Confronting the meat paradox in different cultural contexts: Reactions among Chinese and French participants. Appetite, 96, 187-194.

Toepel, U., Knebel, J., Hudry, J., Lecoutre, J., \& Murray, M. (2009). The brain tracks the energetic value in food images. Neuroimage, 44, 967-974.

Tremoulet, P. D., \& Feldman, J. (2000). Perception of animacy from the motion of a single object. Perception, 29, 943-951.

Tremoulet, P. D., \& Feldman, J. (2006). The influence of spatial context and the role of intentionality in the interpretation of animacy from motion. Perception \& Psychophysics, 68, 1047-1058.

Vanhamert, K. (2013). Yikes! Three skin-crawling dishes that combine fine dining and synthetic biology. Wired, July 24 ${ }^{\text {th }}$. https://www.wired.com/2013/07/ahhhh-three-skincrawling-dishes-that-combine-fine-dining-and-synthetic-biology/.

Vi, C. T., Marzo, A., Ablart, D., Memoli, G., Subramanian, S., Drinkwater, B., \& Obrist, M. (2017). TastyFloats: A contactless food delivery system. ACM ISS: Interactive Surfaces and Space, October $17-20^{\text {th }}$. Brighton, UK.

Vingerhoets, G. (2014). Contribution of the posterior parietal cortex in reaching, grasping, and using objects and tools. Frontiers in Psychology, 5:151.

Wang, W., Yao, L., Zhang, T., Cheng, C.-Y., Levine, D., \& Ishii, H. (2017). Transformative appetite: Shape-changing food transforms from 2D to 3D by water interaction through cooking. Proceedings of the 2017 CHI Conference on Human Factors in Computing Systems, 61236132. Denver, Colorado, USA - May 6-11 ${ }^{\text {th }}$, 2017. New York, NY ACM Press.

Wilson, E. O. (1984). Biophilia. London, UK: Harvard University Press. 